Article

\title{
Ripening of Nostrano Valtrompia PDO Cheese in Different Storage Conditions: Influence on Chemical, Physical and Sensory Properties
}

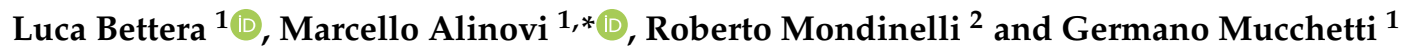 \\ 1 Food and Drug, University of Parma, Parco Area delle Scienze, 47/A 43124 Parma, Italy; \\ luca.bettera@unipr.it (L.B.); germano.mucchetti@unipr.it (G.M.) \\ 2 Consorzio di Tutela del formaggio Nostrano Valtrompia, Via G. Matteotti, 327, 25063 Gardone Val Trompia, \\ Italy; mondinellirob@gmail.com \\ * Correspondence: marcello.alinovi@studenti.unipr.it; Tel.: +39-334-328-3206
}

Received: 21 July 2020; Accepted: 8 August 2020; Published: 12 August 2020

\begin{abstract}
Nostrano Valtrompia is a hard, long-ripened, Italian Protected Designation of Origin (PDO) cheese typically produced by applying traditional cheesemaking practices in small dairies. Due to the limited production, this cheese is characterized by an important market price. Nostrano Valtrompia physico-chemical and sensory quality can be influenced by the duration and conditions of ripening. The objectives of this work were to characterize the physico-chemical and sensory characteristics of Nostrano Valtrompia cheese ripened for 12 and 16 months and to study the influence of different ripening warehouses: a temperature conditioned warehouse (TCW) and in a traditional, not conditioned warehouse (TNCW). The moisture gradient from the rind to the center of the cheese influenced texture, moisture, aw and color. Ripening in different warehouses did not affect the overall appreciation of the cheese nor other physico-chemical (color, moisture) or sensory traits. TCW cheeses were characterized by a slightly softer texture, slightly different openings distribution, and a different sensory perception than TNCW cheeses. These minor differences were related to the less variable environmental ripening conditions of TCW than TNCW. The results of this study can be useful to support the management of the ripening conditions of Nostrano Valtrompia PDO cheese and to rationally introduce new, suitable ripening sites.
\end{abstract}

Keywords: hard cheese; long ripened cheese; ripening rooms; environmental ripening conditions; quantitative descriptive analysis; texture; water activity; image analysis; cheesemaking technology

\section{Introduction}

Nostrano Valtrompia is a registered PDO cheese [1] included into the group of the Italian hard long ripened cheeses produced in the region of the Alps in Northern Italy, including, e.g., Fontina from Valle d'Aosta; Ossolano from Piemonte; Silter, Bagoss and Formai de Mut from Lombardia; Monte Veronese, Piave and Asiago from Veneto; Stelvio from Trentino Alto Adige and Montasio from Friuli Venezia Giulia [2,3].

While the production of the largest part of some of the cited cheeses is today made in industrial sites with modern equipment (e.g., Asiago, Montasio, Fontina, Stelvio or Piave), Nostrano Valtrompia cheese is still manufactured in small dairies that transform a maximum of $300 \mathrm{~kg}$ of milk per day, by applying traditional cheesemaking practices and by the use of traditional equipment $[4,5]$.

The cheese is characterized by a low moisture content ( $\max 36 \%$ ), a fat-to-protein ratio usually lower than 0.85 , a hard but not crumbly texture and the presence of small irregular openings in the structure mainly due to microbial fermentation $[4,5]$. 
The key points of Nostrano Valtrompia cheesemaking technology may be summarized as follows: (i) use of partially skimmed raw milk obtained from up to 4 milking (approximately $300 \mathrm{~kg}$ of milk) to produce wheels complying with the limitations in size provided by the standard $(8-18 \mathrm{~kg})$; (ii) production of one cheese per vat (rarely two), leading to a strong relation between milk amount and size of the cheese; (iii) use of copper vats with single wall heated by fire (from wood or gas burning); (iv) addition of saffron to milk or cheese curd grains (from $0.05 \mathrm{~g}$ to $0.2 \mathrm{~g} / 100 \mathrm{~kg}$ milk) before cooking; (v) cooking of cheese curd granules up to $47-52{ }^{\circ} \mathrm{C}$; (vi) minimum ripening time of 12 months.

The use of an autochthonous natural starter is frequent but not mandatory.

These fundamentals, common to Bagoss cheese produced in a near geographical area [6], may be considered for many aspects as the living memory of the ancient way of making Parmigiano Reggiano cheese before 1900 [7]. An example of how a living memory can become an innovation tool is the case of the use of saffron, an old practice left by Parmigiano Reggiano cheesemakers [8] but kept alive by some Italian cheeses as Nostrano Valtrompia, Bagoss or Piacentinu Ennese [6,9]. The addition of saffron to cheese is today sometimes presented as an innovative practice for ovine dairy products designed for niche markets [10] or to introduce healthy claims for consumers [11].

As a consequence, a better understanding of Nostrano Valtrompia cheese properties may be helpful to evaluate the choices made more than one hundred years ago by Parmigiano Reggiano dairies leading to the actual worldwide success but also to test today alternative ways to preserve this cultural heritage and to maintain the income of these small dairies, producing a cheese with an important market price (more than 22 Euro/kg at the dairy), higher than that of Parmigiano Reggiano cheese, able to repay the strong efforts required to make it.

Cheese characterization is of great interest in order to fulfill the definition of identity, authenticity and quality on the application of policies of the European Union and of the protection and information of consumers [12]. The recent recognition of the PDO status had the effect of creating a growing demand for Nostrano Valtrompia PDO cheese. However, few studies have described the physicochemical and sensory properties of this cheese [4,5].

The ripening method is another distinctive characteristic of Nostrano Valtrompia. Farmers-cheesemakers are rarely also "affineurs", keeping the ancient separation between cheesemakers and "affineurs" typical of the Parmigiano Reggiano area where an important part of the cheese is up to date ripened in large warehouses out of the dairies, storing more than 100,000 wheels. At the same time, the ripening represents a critical step in the Nostrano Valtrompia production. The limited storage capacity within the PDO area cannot satisfy the quantity of cheese produced, considering the minimum ripening period of 12 months imposed by the PDO regulation. This is a limiting factor for the growth of the Nostrano Valtrompia system.

Nostrano Valtrompia cheese ripening is characterized by the traditional practice of coating the surface with linseed oil. Coating is aimed to control both the rate of moisture evaporation and to limit the mold growth [13]. About every ten days, the cheese surface is cleaned with a knife from the film of linseed oil, polymerized because of air contact [14], and then newly oiled.

The large variability of cheese size [1] is responsible for a different evolution of the weight loss caused by moisture evaporation, affecting the $\mathrm{a}_{\mathrm{w}}$ value gradient and the rate of biochemical reactions.

At present, the knowledge about the moisture distribution of hard long-time ripened cheeses is poor, as is that of textural and color properties, partly governed by the moisture content.

The aim of the paper is twofold: (i) analyze some physicochemical and sensory properties of Nostrano Valtrompia PDO cheese useful for its characterization; (ii) investigate whether these properties are affected by different ripening conditions. To reach this goal, cheeses were ripened for 12 and 16 months in a not conditioned traditional cellar and in a temperature conditioned warehouse and were characterized from a physico-chemical, sensory point of view. 


\section{Materials and Methods}

\subsection{Experimental Design}

Experimental design is schematized in Figure 1. Four dairies (1 to 4 ) producing from a maximum of 2 cheeses/day to a minimum of 1 cheese every 3 days were chosen to represent the system of hard cheese production in Trompia Valley. Cheeses considered in this study were produced in the period from May to June 2017.

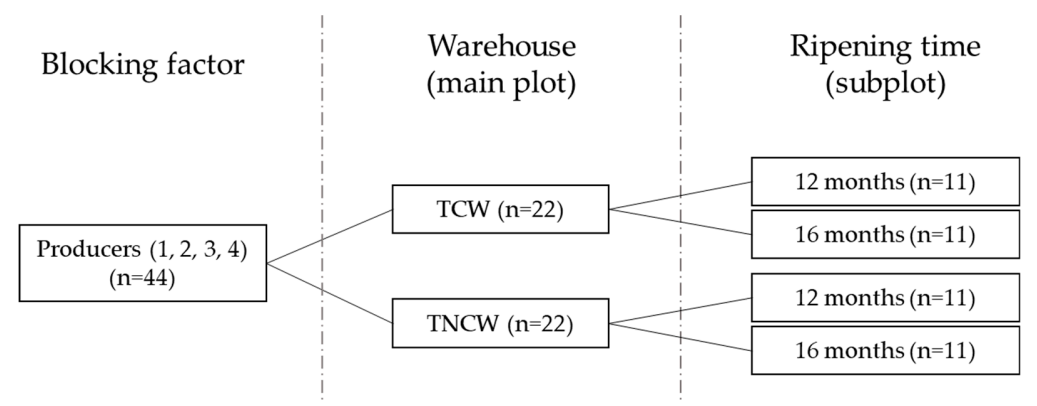

Figure 1. Experimental design schematization. TCW = temperature conditioned warehouse; $\mathrm{TNCW}=$ traditional non conditioned warehouse; $n=$ number of cheeses.

The cheeses were randomly assigned and ripened for 12 and 16 months in two different warehouses: (i) temperature conditioned warehouse (TCW) (Formaggi Tre Valli, San Colombano, BS, Italy); (ii) traditional, not conditioned warehouse (TNCW) (Azienda Agricola Mauro Beltrami, Marmentino, BS, Italy).

\subsection{Cheese Making}

Dairies followed the cheese-making technology described by PDO standard of production. All the dairies used raw milk partially skimmed by spontaneous creaming and added saffron $(\sim 0.1 \mathrm{~g} / 100 \mathrm{~kg}$ milk). The amount of milk used has been $184 \pm 57 \mathrm{~kg}$ derived from one to three milkings.

The main features of the process are reported in Table 1. Values of $\mathrm{pH}$ and temperature during processing operations were measured with a Portamess pH-meter mod. 913 (Knick Elektronische, Berlin, Germany), equipped with a Double Pore F electrode (Hamilton Company, Reno, NV, USA) and a pt-1000 temperature probe.

Table 1. Duration of key Nostrano Valtrompia cheese manufacture steps and relative values of $\mathrm{pH}$, temperature (expressed in ${ }^{\circ} \mathrm{C}$ ) of milk and curd at the end of each cheese making step.

\begin{tabular}{ccccccc}
\hline \multirow{2}{*}{ Cheese Making Step } & \multicolumn{2}{c}{ Duration $(\mathbf{m i n})$} & \multicolumn{2}{c}{$\mathbf{T}\left({ }^{\circ} \mathbf{C}\right)$} & \multicolumn{2}{c}{$\mathbf{p H}$} \\
\cline { 2 - 7 } & Mean & \pm SD & Mean & \pm SD & Mean & \pm SD \\
\hline Milk in cheese vat & N.A. & N.A. & 20.75 & 2.39 & 6.51 & 0.10 \\
Heating until coagulation & 32.40 & 11.49 & 38.07 & 0.90 & 6.39 & 0.08 \\
Coagulation (from rennet addition to gel cutting) & 44.90 & 21.09 & 37.56 & 2.07 & 6.32 & 0.11 \\
Cooking & 19.00 & 7.80 & 50.06 & 1.70 & 6.11 & 0.19 \\
Curd resting under whey & 40.33 & 17.44 & 49.89 & 1.49 & 5.93 & 0.33 \\
\hline
\end{tabular}

Raw milk was initially heated into copper vats using direct wooden fire until reaching a temperature of $38.1 \pm 0.9$. Two out of the four dairies (producers 2 and 4$)$ used a low dosage $(\sim 0.2-0.5 \% \mathrm{v} / \mathrm{v})$ of natural whey starters, while the other two (producers 1 and 3) did not use any starter. Milk was coagulated by adding powdered calf rennet (1:125,000 Soxhlet units).

After coagulation, the coagulum was cut using a blade and a whisk by producers 1 and 2, or only with the whisk by producers 3 and 4 . After cutting, the cheese curd grains were cooked for a variable amount of time $(19 \pm 8 \mathrm{~min})$ until reaching a final temperature of $50 \pm 2{ }^{\circ} \mathrm{C}$. 
After cooking, the curd rested for $40 \pm 17$ min under hot whey, in order to allow for the reciprocal junction of the cheese curd particles and to favor whey syneresis, and it was finally extracted and molded with a linen cloth. Molded curds were overturned for two times to complete whey drainage and they were then dry salted a variable period from 2 to 11 days, depending on cheese weight and the choice of each cheesemaker.

Cheeses were stored after salting for a 7-days storage period in TCW warehouse and then half of them were addressed to the other ripening warehouse TNCW as reported in Section 2.1.

\subsection{Temperature and Relative Humidity Monitoring during Ripening}

During cheeses ripening, temperature and relative humidity ( $\mathrm{RH} \%$ ) of the warehouses were continuously monitored with data loggers (Hygrolock, Rotronic, Hauppauge, NY, USA). Data were acquired with software HW4 (Rotronic, USA) during the ripening period with $1 \mathrm{~h}$ timesteps.

\subsection{Cheese Physico-Chemical Characteristics}

\subsubsection{Cheese Sampling}

To perform analyses after 12 and 16 months of ripening, cheese wheels were classified and portioned in representative parts of the wheels (slices of $\sim 1.5 \mathrm{~kg}$ ) (Figure 2a), they were under-vacuum packaged and stored at $4 \pm 1{ }^{\circ} \mathrm{C}$ before being analyzed. The cheese slices were divided into three zones (Figure 2d): rind, defined as the external part of cheese with a depth of $0.5 \mathrm{~cm}$; underrind, defined as the part of cheese with a depth between $0.5 \mathrm{~cm}$ and $1.5 \mathrm{~cm}$ and inner part of the cheese. This subdivision was made in order to highlight the possible influence of the two different ripening conditions (TCW, TNCW) and times (12, 16 months) in the different locations of the cheese. While image analysis features and sensory properties were measured only in the inner part of the cheese, the other physico-chemical parameters (water activity, moisture content, textural features, color) were assessed in the three different zones. Furthermore, textural and color measurements were performed in specific points of the slice within each of the three zones (Figure 2b,c). The distance of the points was normalized to 100 in function of the slice length, height (for underrind and inner part) and thickness (for the rind).

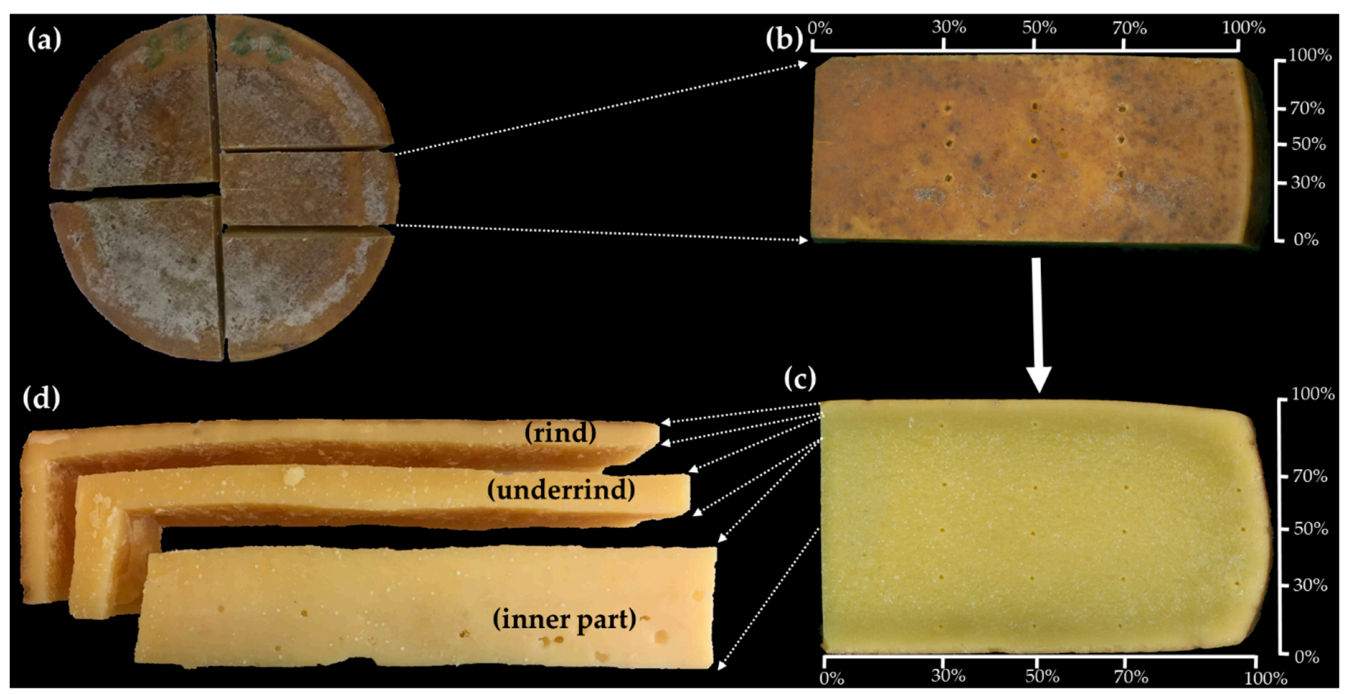

Figure 2. Cheese sampling and analysis schematization. (a) cheese wheel seen from the top: portioning of a representative slice; (b) focus on the rind: specific textural and color analysis points at 30-50-70\% of slice length and thickness; (c) focus on the underrind and inner part: specific textural and color analysis points at $30-50-70 \%$ of slice length and height; (d) cheese zones subdivision: rind, underrind (part with a depth between $0.5 \mathrm{~cm}$ and $1.5 \mathrm{~cm}$ ) and inner part. 


\subsubsection{Moisture Content and Water Activity}

Moisture content of cheeses was measured by oven-drying samples at $102{ }^{\circ} \mathrm{C}$ [15] until a constant weight was reached. The measurements were performed in triplicate.

Water activity $\left(\mathrm{a}_{\mathrm{W}}\right)$ of cheese samples was measured at $25^{\circ} \mathrm{C}$ using an AquaLab Water Activity Meter Series 3TE with internal temperature control (Decagon Devices, Inc., Pullman, WA, USA).

\subsubsection{Colorimetric Characteristics}

Color of the different zones of cheese was measured using a Minolta Colorimeter (CM 2600d, Minolta Co., Osaka, Japan) equipped with a standard illuminant D65. The assessments were carried out at room temperature $\left(25^{\circ} \mathrm{C}\right)$. CIELAB color space was considered, and the parameters $L^{*}$ (lightness, black $=0$, white $=100), a^{*}$ (redness $>0$, greenness $\left.<0\right), b^{*}$ (yellowness $>0$, blue $<0$ ) were determined for each sample.

\subsubsection{Textural Properties}

Texture analysis of the cheeses was performed by means of a TA.XTplus Texture Analyzer (Stable Micro Systems, Godalming, UK) equipped with a $30 \mathrm{~kg}$ load cell and a stainless steel cylindrical probe with a $3 \mathrm{~mm}$ diameter (SMS P/3, Stable Micro Systems) according to a previously described penetration test [16]. Young's modulus, stress and strain at fracture were calculated according to Hort and Le Grys [17], from true strain $(\varepsilon)$ and true stress $(\delta)$ parameters [18] (Equations (1) and (2)):

$$
\begin{gathered}
\varepsilon=\ln \left(h_{0} /(h 0-\Delta h)\right) \\
\delta(t)=F(t) / A(t)
\end{gathered}
$$

where $h_{0}$ is the original height $(\mathrm{m}), \Delta h$ represent the change in height of the sample $(\mathrm{m}), F(t)$ is the force at time $(\mathrm{t})$, and $A(t)$ is the surface area at time $(\mathrm{t})$.

\subsubsection{Image analysis}

Image analysis of cheese slices was performed to estimate the presence of openings ("eyes" and/or "cracks") of the paste. Images of slices of cheese samples $(0.21 \times 0.30 \mathrm{~mA} 4$ scanner size $)$ were acquired using a Hewlett Packard Scanjet 8200 scanner (Palo Alto, CA, USA) with a resolution of 600 dpi (corresponding to 236 pixels $\mathrm{cm}^{-1}$ ) and saved in TIFF format. A black background was used to enhance the contrast of acquired images. Images were preprocessed by adjusting the parameters of brightness, contrast and gamma using a software (XnConvert 1.73, XnSoft Corp., Reims, France). Image analysis was performed with Matlab ${ }^{\circledR}$ R2018 b software (The MathWorks Inc., Natick, MA, USA), using the three following applications: (i) Color Thresholder to select the proper ranges of RGB (red, green, blue) channels of the color space that were applied to every cheese image to create a binary representation of the features-of-interest, according to Caccamo et al. [19]. Chosen values were: R: $\min =0-\max =255,000 ; \mathrm{G}: \min =0-\max =76,000 ; \mathrm{B}: \min =0-\max =255,000$; (ii) Image Segmenter to crop the area of cheese sample and modify the image in binary scale; (iii) Image Region Analyzer, to estimate the porosity and the shape and size of the openings. Porosity of each opening was calculated according to the following Equation (3):

$$
\text { Porosity }(\%)=(\text { Area of openings/Total area of image }) \times 100
$$

According to preliminary trials, "eyes" were differentiated from "cracks" on the basis of the parameter eccentricity $(e)$ of the ellipse that has the same second-moments as the region, as calculated by the software according to the following Equation (4):

$$
e=c / a
$$


where $c$ is the distance between the foci of the ellipse, and $a$ is its major axis length. The value is between 0 (the ellipse is a circle) and 1 (the ellipse is a line segment); openings having an eccentricity value lower of 0.9 were classified as "eyes"; openings with a value equal or higher than 0.9 were classified as "cracks".

To evaluate the size distribution of openings, the 10th, 50th and 90th percentiles (D10, D50 and D90) were calculated. To summarize the distribution, the span value and the mean size of openings were also calculated. The span value was calculated according to Equation (5):

$$
\text { Span }=(\mathrm{D} 90-\mathrm{D} 10) / \mathrm{D} 50
$$

\subsection{Sensory Properties}

Sensory properties of cheeses at 12 and 16 months of ripening were evaluated by means of a discrimination triangle test and by a consumer test. Tests were performed by comparing each time the two cheeses of the same dairy, stored in the two different warehouses.

\subsubsection{Discriminant Test}

To perform the discriminant triangle tests, workers and students of the University of Parma were chosen as panelists. The panel group was untrained but had previous experience with sensory analysis. Three samples (cubes of approximately $10 \mathrm{~g}$ ) were placed in white plastic dishes and the panel group (at least 12 members for each sample, with a minimum and maximum age of 18 and 44, respectively) was asked to identify the odd cheese sample. A randomized three-digit code was provided to the panelists and used to identify and mark the samples. Moreover, the panel was also asked to indicate one or more particular sensory attributes responsible for any perceived difference between the samples. A total of 164 tests was performed.

\subsubsection{Descriptive Test}

The consumer test was performed in the geographical production area of Nostrano Valtrompia PDO cheese, in order to involve usual consumers of this cheese. Consumers were asked to taste two cheeses of the same producer stored in the different warehouses and to give a score for each sensory parameter considered using a 1-7 ordinal scale, where 1 represents the lack of the attribute, 7 the excessive presence of the attribute, and 4 is the optimal value. Consumers (162 women and 243 men) evaluated the cheeses in terms of firmness, presence of openings and eyes, color, aroma and taste. Finally, consumers were also asked to give an overall evaluation of cheese appreciation, using a 1-7 ordinal scale, where 1 and 7 represent the minimum and the maximum appreciation, respectively. The samples were cut into cubes of approximately $10 \mathrm{~g}$ and were placed in white plastic dishes; in order to judge the presence of openings and eyes, a slice of the cheese sample was showed to the consumers.

In total, 405 independent sensory evaluations were performed by consumers for cheeses ripened in TCW and 405 evaluations for cheeses ripened in TNCW.

\subsection{Statistical Analysis}

In the case of moisture, $\mathrm{a}_{\mathrm{w}}$, textural and colorimetric parameters, the effects of ripening warehouse and cheese zone were evaluated according to Alinovi et al. $[20,21]$ by developing split plot ANOVA models. The effect of warehouse $\left(W_{i}, i=1,2\right)$ was analyzed in whole-plot, and the different cheese producer $\left(P_{j}, j=1,2,3,4\right)$ was used as the blocking factor; in the subplot the effects of ripening time $\left(R t_{k}, k=1,2\right)$ and of warehouse $\times$ cheese zone $(W \times R t)$ were analyzed (Equation (6)):

$$
Y_{i j k l}=\mu+W_{i}+P_{j}+\delta_{i j}+R t_{k}+(W \times R t)_{i k}+\gamma_{i j k}
$$

where $\delta_{i j}, \gamma_{i j k}$, were the main plot and the subplot error terms, respectively, and $Y_{i j k l}$ was the selected response variable. 
The effect of the different warehouses on image analysis and consumer test sensory attributes was tested by performing one-way ANOVA models.

Split plot and one-way ANOVA models were built using PRC GLM of SAS (SAS Inst. Inc., Cary, NC, USA); lsmeans with LSD adjustment was used to perform multiple comparisons among means.

For discrimination triangle test, a binomial test was carried out in order to assess if the number of panel's correct classification responses give a higher probability level $(p)$ than a random classification process $(p>1 / 3, \alpha=0.05)$.

\section{Results and Discussion}

\subsection{Warehouses Environmental Conditions}

Among the several factors influencing the cheese ripening, temperature and relative humidity $(\mathrm{RH} \%)$ of the warehouses play an important role in regulating the mass transfer between the cheese and the environment and the biochemical reactions rate.

By monitoring the environmental conditions, it was possible to reveal important differences between the two warehouses, as reported in Figure 3. TNCW was characterized by higher temperatures $\left(13.4 \pm 3.3^{\circ} \mathrm{C}\right.$, compared to $10.1 \pm 0.7^{\circ} \mathrm{C}$ of TCW) and in general by a large temperature variation during the whole ripening period (Figure $3 \mathrm{a}$ ); this was caused by the seasonal temperature variations and the absence of temperature control in the case of TNCW. In TNCW, temperatures reached higher peaks of $21.3{ }^{\circ} \mathrm{C}$ during the summer and lower peaks of $5.9^{\circ} \mathrm{C}$ during the winter.

Moreover, TNCW showed also larger variations of temperature in a short time scale, that were due to the daily thermal excursion between day and night (Figure $3 b$ ).

On the other hand, temperature of TCW was quite constant over the year, and it did not suffer of daily temperature variations, thanks to the room temperature control (Figure $3 a, b$ ).

Concerning $\mathrm{RH} \%$, the two ripening rooms showed similar mean values and a similar high variability during 1-year period $(89.6 \pm 4.8 \%$ for TCW and $91.3 \pm 5.0 \%$ for TNCW), that can also be observed in Figure 3c. It is important to note that strong $\mathrm{RH} \%$ variations were present also in the case of TCW, since for this room, temperature was controlled, but there was no control of relative humidity. The $\mathrm{RH} \%$ in the two warehouses was largely overlapped during the 1-year period, despite a clear deviation being observable from May 2018, with TNCW showing higher RH\% ( 95\%) than TCW ( $\sim 5 \% \%)$; this divergence continued until the end of the ripening period (result not shown).

In the case of TNCW, the lack of temperature control led to a small humidity variation that could be observed in a short time scale (Figure 3d) and that followed the daily thermal excursion observed in Figure $3 \mathrm{~b}$. This short-scale variation of $\mathrm{RH} \%$ was not present in the case of TCW.

In general, the mean $\mathrm{RH} \%$ value of the warehouses, which was found to be around $90 \pm 5 \%$, was slightly higher than the values reported for other Italian PDO hard or semi-hard, long ripened cheeses. Ripening conditions reported for Parmigiano-Reggiano cheese showed RH values from $74 \%$ to $85 \%$ [22] or more recently around $85 \%$ [3], while Asiago d'Allevo cheese is ripened at RH\% of $80 \pm 5 \%$ [23]. Conversely, the measured mean temperature of ripening of Nostrano Valtrompia, that is around $12 \pm 3{ }^{\circ} \mathrm{C}$, was found to be slightly lower to the one reported for the Parmigiano Reggiano cheese and in the same range of those cited for Asiago d'Allevo and Montasio [3,24-27]. Temperature and relative humidity reported in our study were in line with those previously reported by Mucchetti et al. [4], which monitored the environmental conditions for Nostrano Valtrompia ripened in both temperature-controlled and non-controlled warehouses. 
Foods 2020, 9, 1101

8 of 18
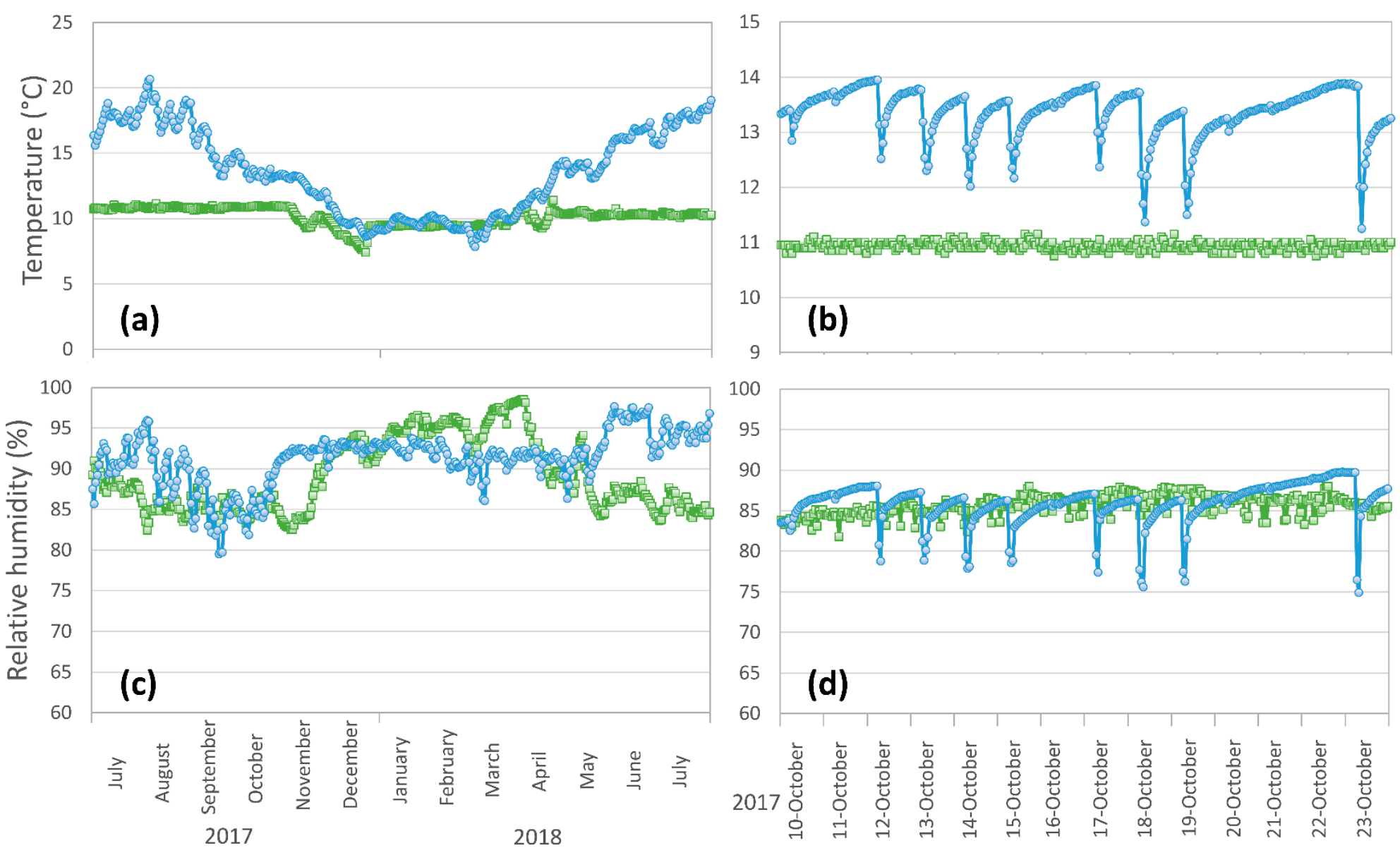

Figure 3. Temperature and relative humidity of Nostrano Valtrompia warehouses: temperature not conditioned warehouse (TNCW) $(0)$ and temperature conditioned cellar (TCW) (口). Panels: (a) temperature variations over 1-year ripening period (July 2017-July 2018); (b) temperature variations over 2-week ripening period (10-23 October 2017); (c) relative humidity variations over 1-year ripening period (July 2017-July 2018); (d) relative humidity variations over 2-week ripening period (10-23 October 2017). 


\subsection{Moisture and Water Activity of the Cheese}

Moisture content and water activity results are reported in Table 2.

Table 2. Moisture content and water activity $\left(\mathrm{a}_{\mathrm{w}}\right)$ of Nostrano Valtrompia cheeses ripened for 12 and 16 months in temperature conditioned warehouse (TCW) and traditional non conditioned warehouse (TNCW).

\begin{tabular}{|c|c|c|c|c|c|c|c|}
\hline \multirow{2}{*}{ Warehouse } & \multirow{2}{*}{$\begin{array}{l}\text { Ripening Time } \\
\text { (Months) }\end{array}$} & \multicolumn{3}{|c|}{$\begin{array}{c}\text { Moisture \% (w/w) } \\
\text { Mean } \pm \text { SD }\end{array}$} & \multicolumn{3}{|c|}{$\begin{array}{l}\text { Water Activity }\left(a_{w}\right) \\
\text { Mean } \pm \text { SD }\end{array}$} \\
\hline & & Rind & Underrind & Inner part & Rind & Underrind & INNER PART \\
\hline \multirow{2}{*}{ TCW } & 12 & $16.1^{\mathrm{a}} \pm 2.0$ & $24.7^{\mathrm{a}} \pm 2.1$ & $32.0^{\mathrm{a}} \pm 1.2$ & $0.882^{a} \pm 0.012$ & $0.919^{\mathrm{a}} \pm 0.009$ & $0.931^{\mathrm{a}} \pm 0.006$ \\
\hline & 16 & $14.4^{\mathrm{a}} \pm 1.0$ & $22.7^{b} \pm 1.4$ & $30.7^{b} \pm 0.9$ & $0.855^{b} \pm 0.017$ & $0.904^{\mathrm{b}} \pm 0.011$ & $0.922^{b} \pm 0.009$ \\
\hline \multirow{2}{*}{ TNCW } & 12 & $15.1^{\mathrm{a}} \pm 1.3$ & $24.6^{a} \pm 1.3$ & $30.7^{b} \pm 1.1$ & $0.872^{\mathrm{ab}} \pm 0.008$ & $0.908^{c} \pm 0.007$ & $0.922^{b} \pm 0.006$ \\
\hline & 16 & $15.6^{\mathrm{a}} \pm 1.2$ & $24.5^{\mathrm{a}} \pm 1.5$ & $30.5^{b} \pm 1.0$ & $0.860^{b} \pm 0.014$ & $0.895^{c} \pm 0.010$ & $0.909^{c} \pm 0.007$ \\
\hline
\end{tabular}

In ripened cheeses, moisture gradients are present in the wheel [16]. As expected, the different zones of the cheese showed clear differences for both measured parameters; these differences reflected the moisture loss and migration phenomena involved during the ripening time of hard, long-ripened cheeses as Nostrano Valtrompia. The moisture content of the different cheese zones was found to be slightly lower than moisture data of Parmigiano Reggiano PDO cheese, which was found to have a moisture of $32.0 \pm 1.4 \%, 26.7 \pm 2.3 \%$ and $18.0 \pm 2.2 \%$, for inner part, underrind and rind at 12 months of ripening time, respectively [16]. These values were found to be in the range of those reported for Gouda cheese, despite the inner-outer moisture difference in Nostrano Valtrompia being higher [28]. In particular, the lower moisture content of Nostrano Valtrompia in the outer part of the cheese may indicate a stronger moisture loss; as the environmental conditions were similar or even less favorable for moisture loss than in the case of Parmigiano-Reggiano, the slightly lower moisture content of Nostrano Valtrompia can be a consequence of the higher surface to volume ratio and smaller cheese wheel dimensions if compared to Parmigiano-Reggiano [2,3,25].

As it is possible to observe, TCW cheeses showed a significant moisture loss between 12 and 16 months of ripening time in the case of the underrind and of the inner part of the cheese $(-2.0 \%$ and $-1.3 \%$, respectively). On the contrary, TNCW did not show a significant decrease of moisture between 12 and 16 months $(p>0.05)$, as a possible consequence of the $\mathrm{RH} \%$ rise observed from May 2018 (Figure 3). Surprisingly, the rind part of the cheese did not show a significant effect of ripening time $(p>0.05)$.

At 12 months of ripening time, TCW showed a slightly higher moisture content than TNCW; however, this difference was not significant in the different cheese zones, with the exception of the inner part of the cheese. At 16 months of storage, this slight difference in moisture was equilibrated, because of the previously described decrease of moisture of TCW cheeses.

Water activity $\left(\mathrm{a}_{\mathrm{W}}\right)$ followed a decreasing trend from 12 to 16 months of ripening time for both TCW and TNCW cheeses. The decrease of this parameter was significant $(p<0.05)$ for all the different cheese zones. In particular, it should be noted that the decrease of $a_{w}$ for TNCW cheeses was not related to a decrease in the moisture content. This decrease could be then mainly due to the breakage of proteins in peptides during ripening and the consequent formation of ionic groups that can bind water [29]. The values and distribution of $\mathrm{a}_{\mathrm{w}}$ among zones were comparable to those measured in Trentin Grana cheeses ripened for 9 and 18 months [30] and in Gouda [28] and slightly higher than those reported for Asiago d'Allevo [23].

The underrind and the inner zone of the cheese showed a significant main effect of the warehouse for $\mathrm{a}_{\mathrm{w}}(p<0.05)$; in particular, $\mathrm{a}_{\mathrm{w}}$ was slightly lower in the case of TNCW than TCW. Without other experimental variables, this difference can be explained by the different temperature of ripening of the two warehouses (Figure 3). A higher ripening temperature in the case of TNCW may be responsible for a higher rate of proteolysis in the cheese matrix [31] that may cause an improvement in the 
water binding capacity because of the increase of hydrophilic interactions caused by the release of peptides [32].

For both moisture content and $\mathrm{a}_{\mathrm{w}}$, the blocking factor, represented by the different cheese producers, did not show a significant main effect in none of the cheese zones $(p>0.05$, results not shown); consequently, the natural starters used by producers 2 and 4 did not show an impact on these cheese parameters.

\subsection{Textural Changes of the Cheese}

The changes in textural parameters of Nostrano Valtrompia cheeses are reported in Figure 4a-c. The textural parameters considered (Young's modulus, strain and stress at fracture) followed the opposite trend of the moisture content reported for the different zones of the cheese (Table 2) in accordance with [16]; accordingly, moisture content was found to be negatively correlated with textural parameters $(-0.838,-0.817,-0.754$ for Young's modulus, stress and strain at rupture, respectively).

In particular, Young's modulus has been demonstrated to have a good correlation with sensory firmness, in the case of hard cheeses [33]. This parameter in the inner part of the cheese, which ranged between $\sim 1.5$ and $\sim 3.5 \mathrm{MPa}$, was found to be higher than literature data of Parmigiano-Reggiano cheese ( 1.3 MPa at 12 months of ripening) [34]. This value was also higher than the one reported for other hard and semi-hard cheeses that are usually ripened for a shorter time than Nostrano Valtrompia and some of them are obtained with whole milk, such as Gouda [35,36], Pecorino [37], Manchego [38], Reggianito Argentino [39] and Cheddar [17,40].

The cheese rind was found to be more elastic than, in order, the underrind and the inner part of the cheese, which were found to be more brittle and fragile [16,41].

In general, Young's modulus and stress at fracture slightly increased as a consequence of the increasing ripening time (from 12 to 16 months) in all the measured cheese zones; this trend was in accordance with the one observed in Parmigiano-Reggiano cheese [34]. In particular, the increase of Young's modulus during ripening time was significant $(p<0.05)$ for TNCW cheeses in all the zones; conversely, in the case of TCW cheeses, the increase of this parameter was significant only in the case of the rind zone (Figure 4a). Stress and strain at fracture were significantly affected by ripening time only in the rind part of the cheese $(p<0.05)$ (Figure $4 \mathrm{~b}, \mathrm{c})$; in particular, strain at fracture showed a significant decrease from 12 to 16 months of storage for both TNCW and TCW cheeses, indicating the formation of a more brittle rind, despite the presence of linseed oil on the cheese surface.

By comparing the two different ripening conditions, it was possible to highlight some slight differences; in general, Young's modulus and stress at facture were slightly lower in the case of TCW than in the case of TNCW in all the three cheese zones.

The producer of the cheese (the blocking factor of the design) showed a significant main effect for all the evaluated textural parameters in all the three cheese zones ( $p<0.05$, results not shown), with the exception of rupture force and Young's modulus in the underrind. Cheeses from producer 4 showed the highest stress, strain at fracture and Young's modulus $(5.6 \pm 1.5 \mathrm{MPa}, 2.5 \pm 0.5,4.6 \pm 1.6 \mathrm{MPa}$, respectively), while producer 2 showed the lowest values $(3.1 \pm 0.5 \mathrm{MPa}, 1.5 \pm 0.3,3.8 \pm 1.3 \mathrm{MPa})$. Accordingly, the use of the natural starters did not group producers 2 and 4; therefore, the use of natural straters could not be considered a characterizing point of Nostrano Valtrompia cheesemaking production because of the low dosage and the high bacterial count of the autoctonous microflora that can develop during the early stage of cheesemaking. Differences among producers that can be related to the relatively high variability of cheesemaking steps (Table 1) were intentionally blocked into the statistical model $[42,43]$ in order to more accurately observe differences related to the ripening time and the different warehouses. 

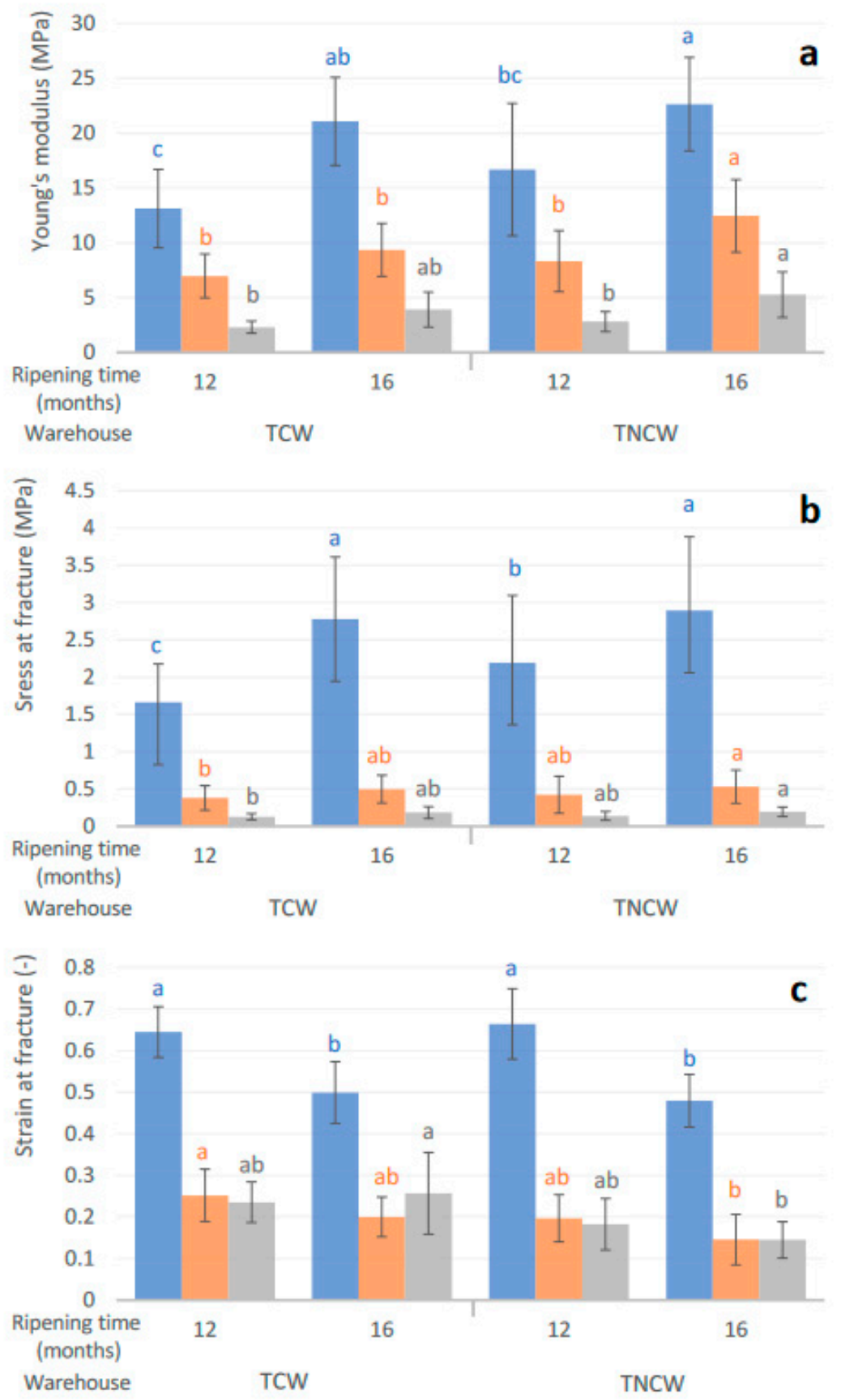

Figure 4. Young's modulus (a), stress (b) and strain at fracture (c) of Nostrano Valtrompia cheeses ripened for 12 and 16 months in temperature conditioned warehouse (TCW) and traditional non conditioned warehouse (TNCW). Blue: rind; orange: underrind; grey: inner part of the cheese. Lower case letters $(a-c)$ indicate significant differences $(p<0.05)$ within the same cheese zone (rind, underrind, inner part).

\subsection{Color Characteristics of the Cheese}

Cheese color is an important quality parameter that can be related to the cheese ripening time and can affect consumer's appreciation $[44,45]$.

As it is possible to observe from Table $3, b^{*}$ values did not show a significant change $(p>0.05)$ in relation with both the ripening time and the warehouses considered in this study; on the contrary, $L^{*}$ value showed a significant increase $(p<0.05)$ between 12 and 16 months of ripening time in the case 
of TNCW cheeses in the inner and in the underrind zone. Moreover, the $a^{*}$ value showed a significant but slight increase during ripening $(p<0.05)$ in the case of TNCW cheeses in the underrind zone.

Table 3. Color parameters of Nostrano Valtrompia cheeses ripened for 12 and 16 months in temperature conditioned warehouse (TCW) and traditional non conditioned warehouse (TNCW).

\begin{tabular}{|c|c|c|c|c|c|}
\hline Color Parameter & Warehouse & Ripening Time (Months) & Rind & $\begin{array}{l}\text { Cheese Zone } \\
\text { Underrind }\end{array}$ & Inner Part \\
\hline \multirow{4}{*}{$L^{*}$} & \multirow{2}{*}{ TCW } & 12 & $50.7 \pm 4.8$ & $58.3^{b} \pm 2.8$ & $66.1^{\mathrm{b}} \pm 5.8$ \\
\hline & & 16 & $48.6 \pm 1.9$ & $59.2^{\mathrm{ab}} \pm 2.5$ & $67.5^{\mathrm{ab}} \pm 4.1$ \\
\hline & \multirow{2}{*}{ TNCW } & 12 & $49.3 \pm 3.9$ & $58.3^{b} \pm 3.5$ & $65.8^{\mathrm{b}} \pm 6.1$ \\
\hline & & 16 & $48.8 \pm 5.4$ & $61.0^{\mathrm{a}} \pm 3.1$ & $70.2^{\mathrm{a}} \pm 2.9$ \\
\hline \multirow{4}{*}{$a^{*}$} & \multirow{2}{*}{ TCW } & 12 & $8.0 \pm 1.1$ & $-1.0^{\mathrm{ab}} \pm 0.9$ & $-0.7 \pm 1.0$ \\
\hline & & 16 & $8.6 \pm 1.2$ & $-0.8^{\mathrm{ab}} \pm 0.8$ & $-0.6 \pm 0.9$ \\
\hline & \multirow{2}{*}{ TNCW } & 12 & $7.0 \pm 2.0$ & $-1.2^{b} \pm 0.8$ & $-1.2 \pm 0.8$ \\
\hline & & 16 & $6.1 \pm 1.9$ & $-0.6^{a} \pm 0.8$ & $-0.8 \pm 1.0$ \\
\hline \multirow{4}{*}{$b^{*}$} & \multirow{2}{*}{ TCW } & 12 & $17.7 \pm 5.6$ & $20.4 \pm 2.8$ & $22.7 \pm 2.7$ \\
\hline & & 16 & $16.7 \pm 3.3$ & $20.2 \pm 3.1$ & $23.5 \pm 3.6$ \\
\hline & \multirow{2}{*}{ TNCW } & 12 & $15.1 \pm 6.3$ & $19.5 \pm 2.0$ & $22.2 \pm 2.9$ \\
\hline & & 16 & $11.9 \pm 3.2$ & $21.1 \pm 3.0$ & $24.0 \pm 3.0$ \\
\hline
\end{tabular}

lowercase letters indicate significant differences $(p<0.05)$ within the same column.

An increase in the lightness index $L^{*}$ during ripening time is an interesting finding for a long-ripened cheese type, as previous studies performed on various ripened cheeses reported a decrease of this parameter during ripening $[23,24,37,46,47]$, that can be due to an increase in the hydration of proteins and a reduction of light scattering related to free water [48]. On the other hand, Sberveglieri et al. [49] recently reported an increase in the $L^{*}$ index of Parmigiano Reggiano cheese during a 36-month period.

$L^{*}$ index was greater in the inner part than in the underrind and in the rind part of the cheese; this was probably due to the presence of a moisture gradient in the cheese zones, as light scattering phenomena can be inversely related to the moisture content [50], and because of the presence of linseed oil in the rind, that showed the lowest $L^{*}$ values.

Cheeses were characterized by a strongly yellow color (high $b^{*}$ values) that can also be related to the use of saffron and that is in line with the values reported for other cheeses manufactured with the addition of saffron [10,11]; because of the stability of crocetin esters from oxidation, during storage time $b^{*}$ value was not lowered [11].

In general, $L^{*}$ values were in line [51] or lower $[47,49]$ with those reported for Parmigiano Reggiano cheese ripened up to 50 months; by considering other PDO ripened Italian cheeses such as Montasio and Asiago cheeses, $L^{*} a^{*} b^{*}$ values were comparable, with the exception of $b^{*}$ values in the case of Asiago, which were lower $[23,24,52]$.

Concerning the different producers, the blocking factor showed significant main effects $(p<0.05$, results not shown) for $a^{*}$ and $b^{*}$ in the underrind and inner part of the cheeses. Differences in color characteristic of the inner part of the cheeses may be caused by the different quantities of saffron used by the producers.

\subsection{Sensory Properties of the Cheeses}

Discriminant triangle test showed that sensorial differences in TCW and TNCW cheeses were successfully detected in $62 \%$ and $63 \%$ of the cases, for cheeses ripened for 12 and 16 months, respectively. Therefore, TCW and TNCW were significantly sensorially different at both 12 and 16 months of storage $(p<0.001)$.

The descriptive sensory analysis performed by local consumers of Nostrano Valtrompia cheese, whose results are reported in Figure 5, allowed to observe different evaluations related to both the ripening warehouse and time. In particular, TNCW cheeses at 16 months of ripening time were 
characterized by a differently $(p<0.05)$ perceived presence of openings and eyes than TCW cheeses and TNCW at 12 months of ripening. This result is in accordance with the higher apparent porosity of TNCW cheeses, measured with image analysis (Section 3.6); as previously stated, it can be related to the different temperature environmental conditions of this warehouse, which showed larger daily and seasonal variations and higher maximum temperatures than TCW [53]. Concerning the overall appreciation, TCW cheeses ripened for 12 months showed slightly lower but not significantly differently scores $(p>0.05)$ than TNCW cheeses and TCW cheeses at 16 months of storage. Similarly, aroma and taste scores were slightly lower for TCW cheeses when compared with TNCW cheeses; again, this difference was not significant, despite being at the limit of significance $(p=0.07)$. No significant differences were also detected for firmness and color $(p>0.05)$.

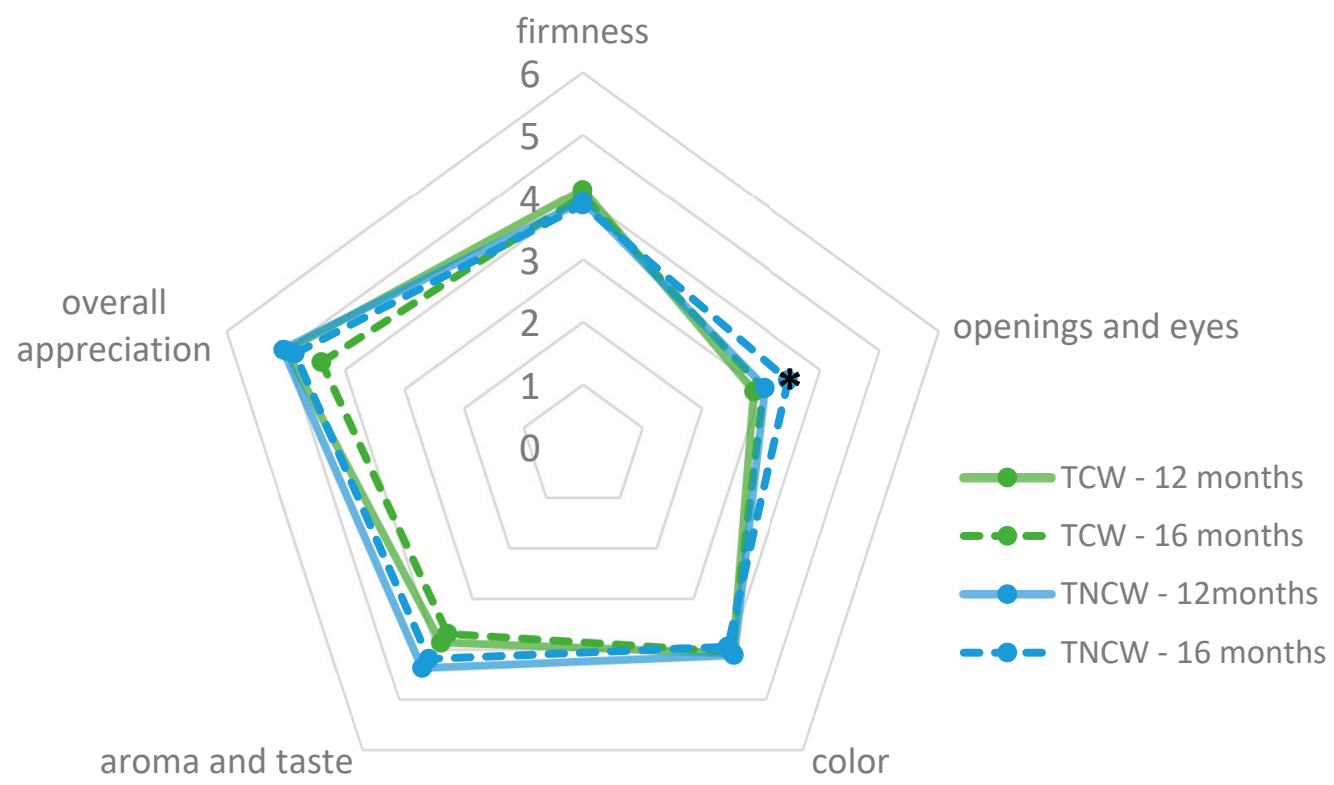

Figure 5. Quantitative descriptive analysis scores (1-7 ordinal scale) for sensory attributes evaluated by Nostrano Valtrompia cheese consumers. The mean score value (4) represents the optimal value for firmness, aroma and taste, color, opening and eyes; for overall appreciation the maximum value of 7 represents the ideal best score. Asterisks $(*)$ represent a significant difference $(p<0.05)$ between treatments for the specific sensory attribute.

Cheese color and the presence of openings and eyes showed the main effect of the blocking factor (producer) ( $p<0.05$, results not shown); on the contrary, the other sensory parameters did not determine a significant main effect of the producer. In particular, for cheese openings and eyes, producer 4 showed the highest score (3.5) while producer 2 the lowest (2.5); conversely, for color, producer 3 (4.7) showed the highest score, while producers 1,2 and 4 determined similar results (3.8, 3.9 and 3.9 , respectively).

\subsection{Cheese Openings}

The presence of openings in the cheese macrostructure can be a typical feature for certain cheese varieties (e.g., eyes in the Swiss-type) or considered defects when a uniform, close texture is wanted [54]. In the case of Nostrano Valtrompia, uniformly distributed medium fine eyes are expected and accepted [1-3]. Figure 6a-d show the paste appearance of Nostrano Valtrompia ripened in TCW and TNCW, for 12 and 16 months. The use of image analysis allowed the definition of size $\left(\mathrm{mm}^{2}\right)$ and shape of the openings. 

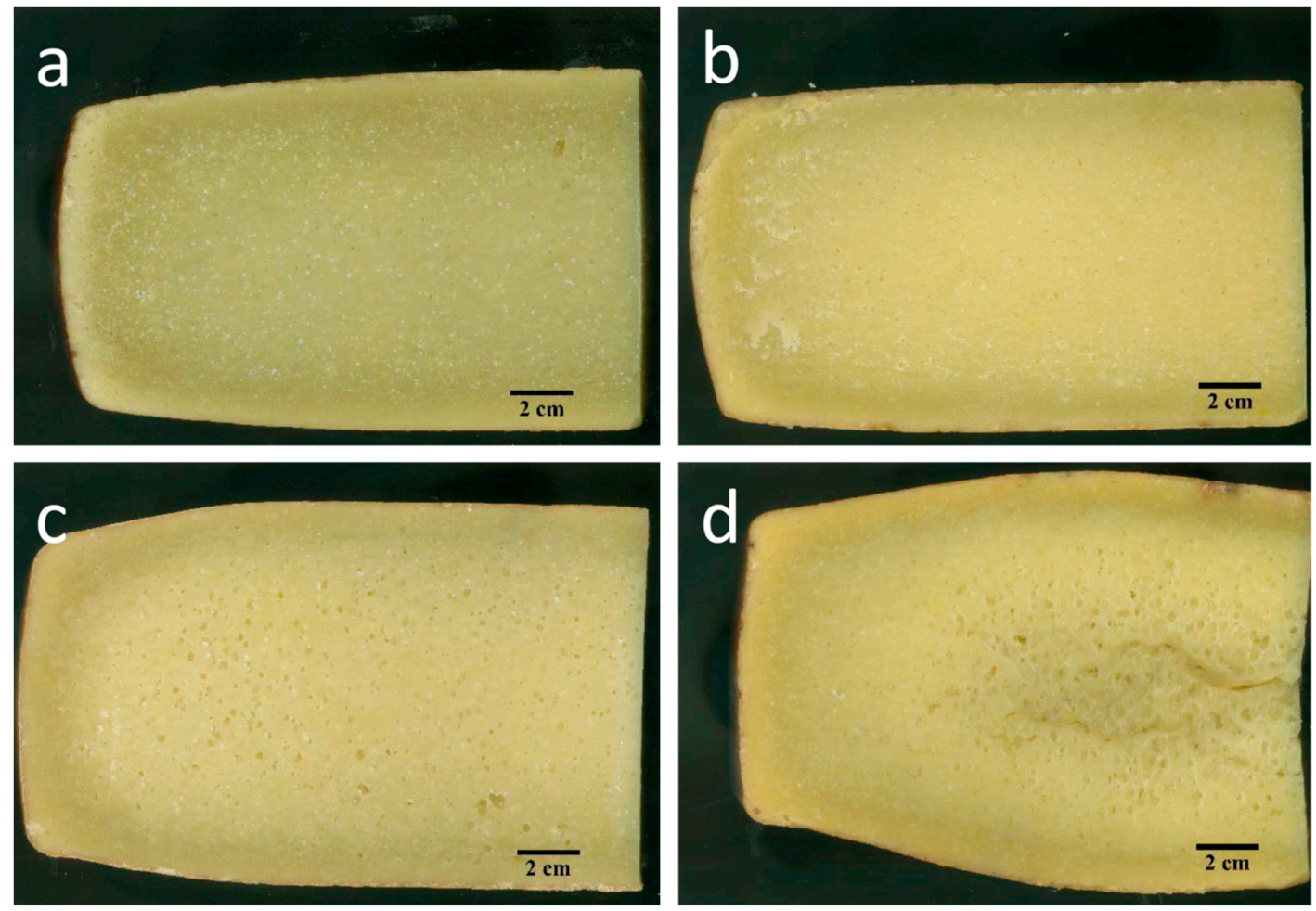

Figure 6. Images of Nostrano Valtrompia cheeses ripened for 12 and 16 months in temperature conditioned warehouse (TCW) and traditional non conditioned warehouse (TNCW). (a) TCW at 12 months of ripening; (b) TCW at 16 months of ripening; (c) TNCW at 12 months of ripening; (d) TNCW at 16 months of ripening.

In general, the porosity of Nostrano Valtrompia cheese due to eyes was higher in the case of TNCW $(1.17 \pm 1.58 \%)$ than TCW cheeses $(0.56 \pm 1.03 \%)$, despite not being significantly different $(p>0.05)$. Moreover, the mean porosity due to cracks or splits was higher but not significantly different $(p>0.05)$ for TNCW $(1.86 \pm 2.32 \%)$ than TCW cheeses $(0.33 \pm 0.38 \%)$. The high variability encountered in the porosity of Nostrano Valtrompia cheese can be a consequence of the artisanal and not standardized cheese making procedure (Table 1) performed for this kind of cheese (e.g., commercial/selected starters are not used) and to the microbial diversity of raw milk that could promote different fermentative phenomena [3,55]. Total porosity of Nostrano Valtrompia cheeses ranged between $0.0 \%$ and $10.6 \%$, with a mean value of $2.0 \pm 2.5 \%$. In particular, the mean value, as expected, was lower than that reported in the case of Swiss-type cheeses (higher than 9.4\%) [56] but also lower than that of Montasio cheese ranging from $3.1 \%$ to $18.3 \%$ ) [57]. On the contrary Nostrano Valtrompia cheese porosity was higher than that reported for blue cheeses $(\sim 0.10-0.05 \%)$ [58] or Pecorino cheese $(\sim 0.2 \%)$ [37].

Figure S1a-d (Supplementary Material) show a highly distorted, right-skewed size distribution for all the tested ripening times; the most frequent opening size was around $\sim 0.5 \mathrm{~mm}^{2}$ to $\sim 6 \mathrm{~mm}^{2}$ for all the treatments. This can also be observed from the highly different mean and median (D50) opening size parameters (Table 4). Other authors reported a similar right-skewed size distribution in the openings of blue cheese [55] and hard/semi-hard Swiss-type cheeses [56,59]. Comparing the two warehouses, it is possible to observe a greater presence of large openings in cheese stored in TNCW; however, this slight variation was not reflected by a significant influence $(p>0.05)$ on the D90 parameter of the two different warehouses (Table 4). Conversely, D50 showed a significant variation between TNCW and TCW cheeses $(p<0.05)$, with the first ones at 16 months of ripening that showed significantly higher values than TCW at 12 and 16 months $(p<0.05)$. The higher temperature reached during the ripening period in TNCW (Figure 3a) could promote the growth of a different cheese microbiota and/or accelerate the fermentation rate. Considering the presence of mesophilic heterofermentative species 
among the various microorganisms known to contribute to the Nostrano Valtrompia ripening [2,3], a higher temperature could have boosted the production of gaseous metabolites leading to an increase of size and number of openings.

Table 4. Size frequency distribution percentiles (D10, D50, D90), mean and span (Equation (5)) of Nostrano Valtrompia cheese openings measured with image analysis.

\begin{tabular}{ccccccc}
\hline Warehouse & $\begin{array}{c}\text { Ripening Time } \\
\text { (Months) }\end{array}$ & D10 $\left(\mathbf{m m}^{\mathbf{2}}\right)$ & $\mathbf{D 5 0}\left(\mathbf{m m}^{\mathbf{2}}\right)$ & $\mathbf{D 9 0}\left(\mathbf{m m}^{\mathbf{2}}\right)$ & Span $\left(\mathbf{m m}^{2}\right)$ & Mean $\left(\mathbf{m m}^{\mathbf{2}}\right)$ \\
\hline \multirow{2}{*}{ TCW } & 12 & $1.1 \pm 0.4$ & $3.8^{\mathrm{b}} \pm 3.6$ & $15.1 \pm 15.6$ & $3.7 \pm 2.3$ & $6.8 \pm 5.7$ \\
& 16 & $1.0 \pm 0.4$ & $3.0^{\mathrm{b}} \pm 2.7$ & $13.0 \pm 10.6$ & $3.6 \pm 2.7$ & $6.3 \pm 4.2$ \\
TNCW & 12 & $1.0 \pm 0.3$ & $4.5^{\mathrm{b}} \pm 2.1$ & $42.7 \pm 48.2$ & $9.3 \pm 12.3$ & $16.6 \pm 13.9$ \\
& 16 & $2.6 \pm 2.7$ & $6.4^{\mathrm{a}} \pm 4.0$ & $35.5 \pm 27.9$ & $7.3 \pm 7.1$ & $26.7 \pm 33.1$ \\
\hline
\end{tabular}

lowercase letters indicate significant differences $(p<0.05)$ within the same column.

The presence of some cracks, mainly in TNCW cheeses, may be favoured by the low moisture content and by a poor plasticity of the casein network that sometimes locally can originate the crack when the pressure of gas deriving from fermentation is not able to create an eye and fractures the paste and/or by the inability of the cheese to expand its volume when the temperature of the warehouse increases [60].

\section{Conclusions}

Ripening of Nostrano Valtrompia PDO cheeses in a temperature conditioned warehouse (TCW) and in a traditional not conditioned warehouse (TNCW) allowed for the production of cheeses characterized by some different and peculiar traits but that in general were pooled by a common identity. TCW created less variable environmental ripening conditions than TNCW; TCW cheeses were characterized by a slightly softer texture, a slightly different porosity distribution and a different sensory perception than TNCW cheeses. Despite these differences, the overall appreciation of the cheese, as well as other physico-chemical and sensory traits, was not affected by the different ripening conditions.

The results of this study suggest that it is possible to consider different types of warehouses for Nostrano Valtrompia ripening, in order to increase the overall capacity of the Nostrano Valtrompia PDO system to store cheeses until the end of the 12-month ripening period established by the PDO regulation. At present, the high number of cheeses produced in the PDO area exceed the storage capacity. As a consequence, part of these cheeses is ripened in other areas out of PDO borders, and it is excluded from the Nostrano Valtrompia PDO system. The studied relations between cheese storage conditions and quality is the base to evaluate the possibility of introducing new warehouses in the area. These results can be helpful to introduce in the area new warehouses, such as an old mine gallery that could be useful to guarantee a relatively constant temperature and to reduce the need for environmental controls.

Supplementary Materials: The following are available online at http://www.mdpi.com/2304-8158/9/8/1101/s1, Figure S1: Frequency distributions (\%) of Nostrano Valtrompia openings measured with image analysis. Nostrano Valtrompia cheeses were ripened for 12 and 16 months in temperature conditioned warehouse (TCW) and traditional non conditioned warehouse (TNCW). (a) TNCW at 12 months of ripening; (b) TCW at 12 months of ripening; (c) TNCW at 16 months of ripening; (d) TCW at 16 months of ripening.

Author Contributions: Conceptualization, G.M., R.M.; methodology, L.B. and M.A.; software, M.A. and L.B.; validation, L.B. and M.A.; formal analysis, L.B.; investigation, L.B.; resources, G.M. and R.M.; data curation, L.B. and M.A.; writing-original draft preparation, M.A. and G.M.; writing-review and editing, L.B.; visualization, M.A. and L.B.; supervision, G.M.; project administration, G.M. and R.M.; funding acquisition, G.M. All authors have read and agreed to the published version of the manuscript.

Funding: This research was funded by Consorzio Tutela Nostrano Valtrompia DOP, in the frame of the project "Progetto Pilota per la Stagionatura del Formaggio DOP Nostrano Valtrompia in Miniera" grant number 2016/00348318 from Giunta Regionale della Lombardia n. 11567 del 18 dicembre 2015 «Programma di Sviluppo Rurale 2014-2020 della Lombardia. Operazione 16.2.01 Progetti pilota e sviluppo dell'innovazione" and "The APC was funded by Food and Drug Department, University of Parma". 
Conflicts of Interest: The authors declare no conflicts of interest.

\section{References}

1. EC Commission Implementing Regulation (EU) No 629/2012 of 6 July 2012 entering a name in the register of protected designations of origin and protected geographical indications Nostrano Valtrompia (PDO). Off. J. Eur. Union 2012, L182, 12.

2. Mucchetti, G.; Neviani, E. Microbiologia e Tecnologia Lattiero-Casearia; Tecniche nuove: Milan, Italy, 2006; ISBN 8848168175.

3. Gobbetti, M.; Neviani, E.; Fox, P. The Cheeses of Italy: Science and Technology; Springer International Publishing AG: Cham, Switzerland, 2018; ISBN 9783319898544.

4. Mucchetti, G.; Taglietti, P.; Emaldi, G.C.; Mondinelli, R. Influenza di alcuni fattori tecnologici ed ambientali sulle caratteristiche organolettiche del formaggio di Valle Trompia. Latte 1993, 18, 548-556.

5. Mucchetti, G.; Neviani, E.; Carminati, D.; Contarini, G.; Olivari, G.; Mondinelli, R.; Savino, L. Il formaggio "Nostrano" di Valle Trompia: Indagine tecnologica e composizione chimica. Ind. Latte 1985, 21, $23-40$.

6. Mucchetti, G. Tecnologia di caseificazione del formaggio Bagoss. Sci. Tec. Latt. Casearia 1996, 47, 125-135.

7. Addeo, F.; Mucchetti, G. Produzioni casearie tipiche: Aspetti qualitativi. Latte 2001, 26, 56-72.

8. Zannoni, M. Evolution of the sensory characteristics of Parmigiano-Reggiano cheese to the present day. Food Qual. Prefer. 2010, 21, 901-905. [CrossRef]

9. Carpino, S.; Rapisarda, T.; Belvedere, G.; Licitra, G. Volatile fingerprint of Piacentinu cheese produced with different tools and type of saffron. Small Rumin. Res. 2008, 79, 16-21. [CrossRef]

10. Licón, C.C.; Carmona, M.; Molina, A.; Berruga, M.I. Chemical, microbiological, textural, color, and sensory characteristics of pressed ewe milk cheeses with saffron (Crocus sativus L.) during ripening. J. Dairy Sci. 2012, 95, 4263-4274. [CrossRef]

11. Aktypis, A.; Christodoulou, E.D.; Manolopoulou, E.; Georgala, A.; Daferera, D.; Polysiou, M. Fresh ovine cheese supplemented with saffron (Crocus sativus L.): Impact on microbiological, physicochemical, antioxidant, color and sensory characteristics during storage. Small Rumin. Res. 2018, 167, 32-38. [CrossRef]

12. Lebecque, A.; Laguet, A.; Devaux, M.F.; Dufour, É. Delineation of the texture of Salers cheese by sensory analysis and physical methods. Lait 2001, 81, 609-623. [CrossRef]

13. Costa, M.J.; Maciel, L.C.; Teixeira, J.A.; Vicente, A.A.; Cerqueira, M.A. Use of edible films and coatings in cheese preservation: Opportunities and challenges. Food Res. Int. 2018, 107, 84-92. [CrossRef] [PubMed]

14. Juita, J.; Dlugogorski, B.Z.; Kennedy, E.M.; Mackie, J.C. Low temperature oxidation of linseed oil: A review. Fire Sci. Rev. 2012, 1, 3. [CrossRef]

15. AOAC. Official Methods of Analysis of the AOAC. Volume 2, 15th ed.; Association of Official Analytical Chemists, Inc.: Rockville, MD, USA, 1990; Volume 2, ISBN 0-935584-42-0.

16. Alinovi, M.; Mucchetti, G.; Tidona, F. Application of NIR spectroscopy and image analysis for the characterisation of grated Parmigiano-Reggiano cheese. Int. Dairy J. 2019, 92, 50-58. [CrossRef]

17. Hort, J.; Le Grys, G. Developments in the textural and rheological properties of UK Cheddar cheese during ripening. Int. Dairy J. 2001, 11, 475-481. [CrossRef]

18. Hort, J.; Grys, G.; Woodman, J. The relationships between the chemical, rheological and textural properties of cheddar cheese. Lait 1997, 77, 587-600. [CrossRef]

19. Caccamo, M.; Melilli, C.; Barbano, D.M.; Portelli, G.; Marino, G.; Licitra, G. Measurement of gas holes and mechanical openness in cheese by image analysis. J. Dairy Sci. 2004, 87, 739-748. [CrossRef]

20. Alinovi, M.; Cordioli, M.; Francolino, S.; Locci, F.; Ghiglietti, R.; Monti, L.; Tidona, F.; Mucchetti, G.; Giraffa, G. Effect of fermentation-produced camel chymosin on quality of Crescenza cheese. Int. Dairy J. 2018, 84, 72-78. [CrossRef]

21. Alinovi, M.; Rinaldi, M.; Mucchetti, G. Spatiotemporal characterization of texture of Crescenza cheese, a soft fresh Italian cheese. J. Food Qual. 2018, 2018, 1-8. [CrossRef]

22. Guidetti, R.; Mora, R.; Zannoni, M. Effect of storage conditions on Parmigiano-Reggiano cheese. II. Cheese stored with and without air conditioning. Sci. e Tec. Latt. Casearia 1995, 46, 178.

23. Marchesini, G.; Balzan, S.; Segato, S.; Novelli, E.; Andrighetto, I. Colour traits in the evaluation of the ripening period of Asiago cheese. Ital. J. Anim. Sci. 2009, 8, 412-413. [CrossRef] 
24. Aprea, E.; Romanzin, A.; Corazzin, M.; Favotto, S.; Betta, E.; Gasperi, F.; Bovolenta, S. Effects of grazing cow diet on volatile compounds as well as physicochemical and sensory characteristics of 12-month-ripened Montasio cheese. J. Dairy Sci. 2016, 99, 6180-6190. [CrossRef] [PubMed]

25. Malacarne, M.; Summer, A.; Franceschi, P.; Formaggioni, P.; Pecorari, M.; Panari, G.; Mariani, P. Free fatty acid profile of Parmigiano-Reggiano cheese throughout ripening: Comparison between the inner and outer regions of the wheel. Int. Dairy J. 2009, 19, 637-641. [CrossRef]

26. Innocente, N.; Munari, M.; Biasutti, M. Characterization by solid-phase microextraction-gas chromatography of the volatile profile of protected designation of origin Montasio cheese during ripening. J. Dairy Sci. 2013, 96, 26-32. [CrossRef] [PubMed]

27. Gatti, M.; Lindner, J.D.; Gardini, F.; Mucchetti, G.; Bevacqua, D.; Fornasari, M.E.; Neviani, E. A model to assess lactic acid bacteria aminopeptidase activities in Parmigiano Reggiano cheese during ripening. J. Dairy Sci. 2008, 91, 4129-4137. [CrossRef]

28. Salazar, J.K.; Carstens, C.K.; Ramachandran, P.; Shazer, A.G.; Narula, S.S.; Reed, E.; Ottesen, A.; Schill, K.M. Metagenomics of pasteurized and unpasteurized gouda cheese using targeted 16S rDNA sequencing. BMC Microbiol. 2018, 18, 1-13. [CrossRef]

29. Ak, M.M.; Gunasekaran, S. Dynamic Rheological Properties of Mozzarella Cheese During Refrigerated Storage. J. Food Sci. 2006, 61, 566-569. [CrossRef]

30. Cavazza, A.; Franciosi, E.; Poznanski, E.; Monfredini, L.; Settanni, L. The spatial distribution of bacteria in Grana-cheese during ripening. Syst. Appl. Microbiol. 2012, 35, 54-63. [CrossRef]

31. Folkertsma, B.; Fox, P.F.; McSweeney, L.H. Accelerated Ripening of Cheddar Cheese at Elevated Temperatures. Int. Dairy J. 1996, 6, 1117-1134. [CrossRef]

32. Sforza, S.; Cavatorta, V.; Lambertini, F.; Marchelli, R.; Dossena, A.; Galaverna, G. Cheese peptidomics: A detailed study on the evolution of the oligopeptide fraction in Parmigiano-Reggiano cheese from curd to 24 months of aging. J. Dairy Sci. 2012, 95, 3514-3526. [CrossRef]

33. Ibanescu, L.; Allard, T.; Fonseca, F.; Caroline, P.; Buchin, S.; Salles, C.; Dibie, J.; Guichard, E. Relating transformation process, eco-design, composition and sensory quality in cheeses using PO 2 ontology. Int. Dairy J. 2019, 92, 1-10. [CrossRef]

34. Noël, Y.; Zannoni, M.; Hunter, E.A. Texture of Parmigiano Reggiano cheese: Statistical relationships between rheological and sensory variates. Lait 1996, 76, 243-254. [CrossRef]

35. Vandenberghe, E.; Choucharina, S.; De Ketelaere, B.; De Baerdemaeker, J.; Claes, J. Spatial variability in fundamental material parameters of Gouda cheese. J. Food Eng. 2014, 131, 50-57. [CrossRef]

36. Vandenberghe, E.; Charalambides, M.N.; Mohammed, I.K.; De Ketelaere, B.; De Baerdemaeker, J.; Claes, J. Determination of a critical stress and distance criterion for crack propagation in cutting models of cheese. J. Food Eng. 2017, 208, 1-10. [CrossRef]

37. Rinaldi, M.; Chiavaro, E.; Massini, R. Pecorino of appennino reggiano cheese: Evaluation of ripening time using selected physical properties. Ital. J. Food Sci. 2010, 22, 54-59.

38. Martín-Alvarez, P.J.; Cabezas, L. Relationship between sensory and instrimental measurements of texture for artisanal and industrial Manchego cheeses. J. Sens. Stud. 2007, 22, 462-476. [CrossRef]

39. Bertola, N.C.; Bevilacqua, A.E.; Zaritzky, N.E. Rheological Behaviour of Reggianito Argentino Cheese Packaged in Plastic Film During Ripening. LWT-Food Sci. Technol. 1995, 615, 610-615. [CrossRef]

40. Charalambides, M.N.; Williams, J.G.; Chakrabarti, S. A study of the influence of ageing on the mechanical properties of Cheddar cheese. J. Mater. Sci. 1995, 30, 3959-3967. [CrossRef]

41. Patel, H.G.; Upadhyay, K.G.; Miyani, R.V.; Pandya, A.J. Instron texture profile of buffalo milk cheddar cheese as influenced by composition and ripening changes. Food Qual. Prefer. 1993, 4, 187-192. [CrossRef]

42. Tsai, P.W. A study of two types of split-plot designs. J. Qual. Technol. 2016, 48, 44-53. [CrossRef]

43. Alinovi, M.; Wiking, L.; Corredig, M.; Mucchetti, G. Effect of frozen and refrigerated storage on proteolysis and physico-chemical properties of high-moisture citric Mozzarella cheese. J. Dairy Sci. 2020, 103. [CrossRef]

44. Wadhwani, R.; McMahon, D.J. Color of low-fat cheese influences flavor perception and consumer liking. J. Dairy Sci. 2012, 95, 2336-2346. [CrossRef] [PubMed]

45. Buffa, M.N.; Trujillo, A.J.; Pavia, M.; Guamis, B. Changes in textural, microstructural, and colour characteristics during ripening of cheeses made from raw, pasteurized or high-pressure-treated goats' milk. Int. Dairy J. 2001, 11, 927-934. [CrossRef] 
46. Romani, S.; Sacchetti, G.; Pittia, P.; Pinnavaia, G.G.; Dalla Rosa, M. Physical, Chemical, Textural and Sensorial Changes of Portioned Parmigiano Reggiano Cheese Packed under Different Conditions. Food Sci. Technol. Int. 2002, 8, 203-211. [CrossRef]

47. D'Incecco, P.; Limbo, S.; Hogenboom, J.; Rosi, V.; Gobbi, S.; Pellegrino, L. Impact of extending hard-cheese ripening: A multiparameter characterization of Parmigiano reggiano cheese ripened up to 50 months. Foods 2020, 9, 268. [CrossRef]

48. Sánchez-Macías, D.; Fresno, M.; Moreno-Indias, I.; Castro, N.; Morales-delaNuez, A.; Alvarez, S.; Argüello, A. Physicochemical analysis of full-fat, reduced-fat, and low-fat artisan-style goat cheese. J. Dairy Sci. 2010, 93, 3950-3956. [CrossRef]

49. Sberveglieri, V.; Bhandari, M.P.; Carmona, E.N.; Betto, G.; Soprani, M.; Malla, R.; Sberveglieri, G. Spectrocolorimetry and nanowire gas sensor device S3 for the analysis of Parmigiano Reggiano cheese ripening. In Proceedings of the ISOCS/IEEE International Symposium on Olfaction and Electronic Nose, Montreal, QC, Canada, 28-31 May 2017; pp. 9-11.

50. Alinovi, M.; Mucchetti, G. Effect of freezing and thawing processes on high-moisture Mozzarella cheese rheological and physical properties. LWT-Food Sci. Technol. 2020, 124, 109137. [CrossRef]

51. Severini, C.; Bressa, F.; Romani, S.; Dalla Rosa, M. Physical and chemical changes in vacuum packaged Parmigiano Reggiano cheese during storage at 25, 2 and -25C. J. Food Qual. 1998, 21, 355-367. [CrossRef]

52. Cozzi, G.; Ferlito, J.; Pasini, G.; Contiero, B.; Gottardo, F. Application of near-infrared spectroscopy as an alternative to chemical and color analysis to discriminate the production chains of Asiago d'Allevo cheese. J. Agric. Food Chem. 2009, 57, 11449-11454. [CrossRef]

53. Lee, K.; Uegaki, K.; Nishii, C.; Nakamura, T.; Kubota, A.; Hirai, T.; Yamada, K. Computed tomographic evaluation of gas hole formation and structural quality in Gouda-type cheese. Int. J. Dairy Technol. 2012, 65, 232-236. [CrossRef]

54. Martley, F.G.; Crow, V.L. Open texture in cheese: The contributions of gas production by microorganisms and cheese manufacturing practices. J. Dairy Res. 1996, 63, 489-507. [CrossRef]

55. Gatti, M.; Bottari, B.; Lazzi, C.; Neviani, E.; Mucchetti, G. Invited review: Microbial evolution in raw-milk, long-ripened cheeses produced using undefined natural whey starters. J. Dairy Sci. 2014, 97, 573-591. [CrossRef]

56. Schuetz, P.; Guggisberg, D.; Jerjen, I.; Fröhlich-Wyder, M.T.; Hofmann, J.; Wechsler, D.; Flisch, A.; Bisig, W.; Sennhauser, U.; Bachmann, H.P. Quantitative comparison of the eye formation in cheese using radiography and computed tomography data. Int. Dairy J. 2013, 31, 150-155. [CrossRef]

57. Innocente, N.; Corradini, C. Use of an immage analysis technique in the quality control of Montasio cheese. Sci. Tec. Latt. Casearia 1998, 42, 82-94.

58. Kebary, K.M.K.; Morris, H.A. Porosity, Specific Gravity and Fat Dispersion in Blue Cheeses. Food Microstruct. 1988, 7, 153-160.

59. Guggisberg, D.; Fröhlich-Wyder, M.T.; Irmler, S.; Greco, M.; Wechsler, D.; Schuetz, P. Eye formation in semi-hard cheese: X-ray computed tomography as a non-invasive tool for assessing the influence of adjunct lactic acid bacteria. Dairy Sci. Technol. 2013, 93, 135-149. [CrossRef]

60. White, S.R.; Broadbent, J.R.; Oberg, C.J.; McMahon, D.J. Effect of Lactobacillus helveticus and Propionibacterium freudenrichii ssp. shermanii combinations on propensity for split defect in Swiss cheese. J. Dairy Sci. 2003, 86, 719-727. [CrossRef]

(C) 2020 by the authors. Licensee MDPI, Basel, Switzerland. This article is an open access article distributed under the terms and conditions of the Creative Commons Attribution (CC BY) license (http://creativecommons.org/licenses/by/4.0/). 